\title{
Analysis of the scores of competency test
}

\author{
Jana Pasáčková ${ }^{1, *}$ \\ ${ }^{1}$ University of Economics, Department of Mathematics, 13067 Prague, Czech Republic
}

\begin{abstract}
Since decreasing level of knowledge of mathematics is the problem at universities, not only in the Czech Republic, we try to define some reasons for that between our students from different secondary schools. The paper discusses the results of the examinations in mathematics at the university in the Czech Republic. The aim is focused on the differences between the scores of students from different secondary schools. We compare the results of two tests which students have to pass during the semester. In addition, we compare the impact of introducing a new subject called "Math seminar". This seminar should help students to complete their knowledge of topics from mathematics of secondary schools. We observe the improvement of students who passed the Math seminar. We observe the impact of passing the school-leaving exam from mathematics as well. We would like to consider this as a part of a long-term monitoring of students in this study programme and re-analyze unsuccessful students after they pass the course "Math seminar".
\end{abstract}

\section{Introduction}

In the last years, decreasing level of knowledge of mathematics is the problem at all universities in the Czech Republic. I focus on the College of Polytechnics Jihlava (VŠPJ). It was established in 2004 as the first public college of a non-university type in the Czech Republic and is the only public college in the Highlands region. This institution provides Bachelor's study programmes with the duration of six semesters. During the years I have been teaching at the College of Polytechnics Jihlava and at the University of Economics Prague, I have monitored a gradually decreasing level of basic knowledge of mathematics. This situation is a problem at all universities, where students have to attend a mandatory basic course of mathematics. A lack of motivation to study and the insufficient level of mathematical knowledge from primary and secondary schools rank among the most serious causes. This paper was motivated by articles [2-3, 8-11], where the decreasing level of knowledge was discussed as well.

In $[2,3]$, they discuss the links between the level of entry knowledge of mathematics and geometry and students' attitude to lectures, exercises and exams, as well as their preparations for the exam and results of their exams in mathematics at the university. They used the anonymous questionnaires. In [8], they study the cognitive learning processing and applying the knowledge to examples from practice. Interesting is paper [9], where they investigate influences of the fail-rates of students who studied on a Bachelors' degree programme at the selected university. In [11], the differences between the scores obtained by the students of different faculties are discussed.

A lack of motivation to study or the low level of knowledge of students can be caused by their primary and secondary school's teachers, too. The first teacher of mathematics of a student should give him/her not only the knowledge but the interest in discovering as well. The problem in the Czech Republic is the low salary of teachers and the lack of authority between students as well as between the parents. There are articles which are focused on teachers' abilities, for example see [1]. In this paper, they identify the efficiencies of mathematics teachers in middle schools and try to know teachers point of view on the competencies significance. On the other hand, the emphasizing test scores as a measurement of the quality of schools raises several questions. In [4], they think about some of these questions and warn to be cautious in how to use test scores. The another interesting research is [12], where they deal with urban schools and their proportion of ethnic minority students and ethnic minority teachers what appear to have the intended impact on candidates' abilities. We could compare instead of ethnic problem the location of students, because our college is the only public college in the Highlands region. Therefore, many students choose this college not on the grounds of study programme, but because they want to stay home, they do not want to move to another city.

Interesting articles are [6, 7] where the problem of homogeneity of test variants in mathematics, which are

* Corresponding author: jana.pasackova@,vse.cz 
used in admission process, is solved. The analysed data are the results of entrance examination in mathematics at our University of Economics in Prague. That could be another point of view for the continuation of this paper.

Between articles with the similar focus we can mention $[5,10]$. In [5] the results show that the perceived study skills preparation concerning time management and learning skills does have a positive impact on college students' first year study behaviour and academic achievement. The results of [10] suggest that certain minimum levels of enrolment at primary and secondary level represent a necessary condition for the development of functioning higher education. Another relevant result of that analysis is that strong differences between educational institutions at secondary level may be detrimental for tertiary education quality.

I was wondering what the connection between the input knowledge of mathematics skills and types of secondary schools, from which the students apply to VŠPJ, was. I investigated this connection and other factors affecting the level of knowledge of mathematics through a questionnaire. I compared the scores from two tests which student had to pass during one semester. I focused on the type of the secondary school, on the passing the leaving-exam from the mathematics and on the possibility that the students had passed Math seminar yet.

I focused on students of the study programme "Travel and Tourism". Travel and Tourism is one of the two degree programmes within the programme of Economy and Management at the College of Polytechnics Jihlava. The main aim of the study is to provide students with a practically oriented bachelor education in the field of economy which can be used in various branches of tourism industry as well as in other activities.

Mathematics is an important subject of study basics of economic sectors. Therefore, students of the study programme have compulsory mathematics lessons in the first year. There is one-semester course of mathematics in the first semester. The course contains linear algebra and mathematical analysis, as you can see in the syllabus:

- Limits and their basic properties,

- Derivative (l'Hospital rule),

- Monotony of a function, local and global extreme values, concave and convex functions, inflection points,

- Matrix algebra, rank of a matrix, determinants,

- Systems of linear equations.

The emphasis is put on application. Students attend two hours of lectures and two hours of exercises a week. Graduates are able to work with functions of one real variable. Moreover, they become familiar with the basic linear algebra algorithms, which are important tools for linear programming used for optimization of linear problems.

Mathematics is the most problematic subject of all subjects through the whole university studies. Successful completion of these courses requires significant knowledge of the mathematics from the secondary schools that not all students achieve. Since there are no entrance examinations all students have to pass a math competency test during the first two weeks in the first semester.

The article is divided into five sections. After the introduction, the following section gives the summary about the distribution of students. We divide them depending on the type of a secondary school and if they passed the school-leaving exam from mathematics. The third section presents the first test and gives an overview of the scores of the first test. In the fourth section we compare the results of the second test. And the last section is the conclusion.

\section{Distribution of students}

In the first academic semester in 2017, the total amount of students of the study programme "Travel and Tourism" was 160. Almost all of them finished a secondary school this year or the last year. The exact numbers are shown in Table 1.

Table 1. School-leaving exams.

\begin{tabular}{|l|c|c|c|}
\hline $\begin{array}{l}\text { the year of the finish of a } \\
\text { secondary school }\end{array}$ & 2017 & 2016 & other \\
\hline number of students & 117 & 29 & 14 \\
\hline percentage & $73 \%$ & $18 \%$ & $9 \%$ \\
\hline
\end{tabular}

Students came mostly from five types of secondary schools: school of economics, comprehensive school, hotel school, technical school and vocational school. Precise numbers of students are expressed in Table 2 and Graph 1 . We can notice that the majority of students are from hotel schools, which is determined by the study programme.

Table 2. Type of schools.

\begin{tabular}{|l|c|c|}
\hline type & $\begin{array}{c}\text { number of } \\
\text { students }\end{array}$ & percentage \\
\hline schools of economics & 56 & $35 \%$ \\
\hline hotel schools & 74 & $46 \%$ \\
\hline technical schools & 2 & $1 \%$ \\
\hline vocational schools & 14 & $9 \%$ \\
\hline comprehensive schools & 12 & $8 \%$ \\
\hline other & 2 & $1 \%$ \\
\hline
\end{tabular}

Graph 1. Type of schools. 


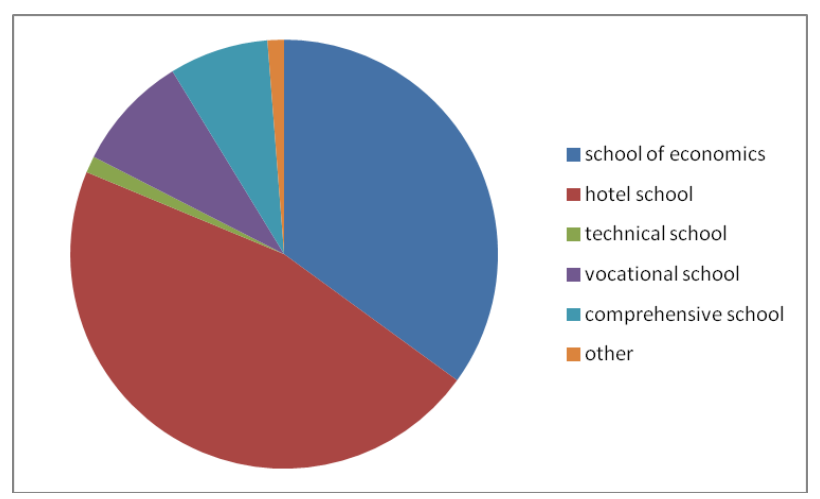

The total number of students who passed the schoolleaving exam from mathematics is 77 , it was $48 \%$ of all students. The numbers of students, who passed the leaving-exam from mathematics, depending on the different types of secondary schools we can see in the Table 3.

Table 3. School-leaving exam.

\begin{tabular}{|l|c|c|}
\hline type & $\begin{array}{c}\text { number of all } \\
\text { students }\end{array}$ & $\begin{array}{c}\text { number of } \\
\text { students who } \\
\text { passed the } \\
\text { leaving-exam } \\
\text { from } \\
\text { mathematics }\end{array}$ \\
\hline school of economics & 56 & 45 \\
\hline hotel school & 74 & 11 \\
\hline technical school & 2 & 1 \\
\hline vocational school & 14 & 9 \\
\hline comprehensive school & 12 & 10 \\
\hline other & 2 & 1 \\
\hline
\end{tabular}

As you can see the majority of students from hotel schools did not pass the leaving-exam from the mathematics. That fact is influenced by the reality that at the hotel schools there are less lessons of mathematics than on other types of schools.

We consider the effect of the type of the secondary school and the influence of the school-leaving exam from mathematics on test results in Mathematics. We assumed that more successful students would be from comprehensive schools and the students who had passed the school-leaving exam from mathematics. This tendency has been confirmed just partially.

\section{Results of the first test}

Students wrote the test during the first two weeks in the semester. The exam was focused on repeating topics from secondary schools (properties of basic functions, equations and inequalities, editing expressions, etc.). Students had 60 minutes and the test consisted of 10 simply tasks and each task was marked $0-2$ points. To pass the exam, it was necessary to obtain at least 11 points of the total 20 . See the example of the test:
1) Find the domain of the function: $f(x)=$ $\frac{x-4}{2 x+1}$ Chyba! Záložka není definována.

2) Solve the inequality: $x^{2}-3 x<0$

3) Simplify the expression: $\left(\frac{1}{a}-\frac{1}{b}\right) \cdot \frac{a^{2}}{a-b}$

4) Simplify the expression: $\sqrt[3]{\mathrm{x} \sqrt[2]{\mathrm{x}}}:\left(\sqrt[3]{\mathrm{x}^{2}}\right)^{4}$

5) Is this function increasing? $f: y=\log x$

6) Sketch the graph of the function: $y=x^{2}-9$.

7) Sketch the graph of the function: $y=5^{x}-1$.

8) Sketch the graph of the function: $y=\sin x-1$.

9) Solve the equation: $\cos \left(x+\frac{\pi}{2}\right)=\frac{\sqrt{3}}{2}$

10) Solve the equation: $3^{x+1}-3^{x-1}=72$

We assumed that more than $50 \%$ of students would passed the test, but as we have had some experiences from previous semesters we knew that it would be less. During the previous semesters there were only about $15 \%$ of students who were able to pass the test. I expected that the best results would have students from comprehensive schools and students who passed the school-leaving exams from mathematics. But the results were different.

Since, of course, the basics of secondary schools' mathematics are needed for the continuing in other courses of mathematics, and to avoid the situation that the majority of the students did not pass the exam from Mathematics, and to avoid the reducing the intensity of the exam, there was a new subject called "Math seminar" introduced at VŠPJ. Students who do not pass this test are transferred into this seminar. During one semester, they will complete their knowledge of topics of secondary schools in this seminar. After that, they will attend the exam again and continue in the subject Mathematics another semester.

Thus, students who passed this seminar do not have to write this test. There were 35 students in this semester who have passed the seminar before.

The first test passed only 21 students from 125 students who had written the test. It means only $16,8 \%$. The highest score of the test was 19 points and the lowest was 0 which was the mode value as well. The arithmetic average was 5 points as well as the median value. You can see the frequency of the points in the Graph 2.

Graph 2. The frequency of the points from the first test. 


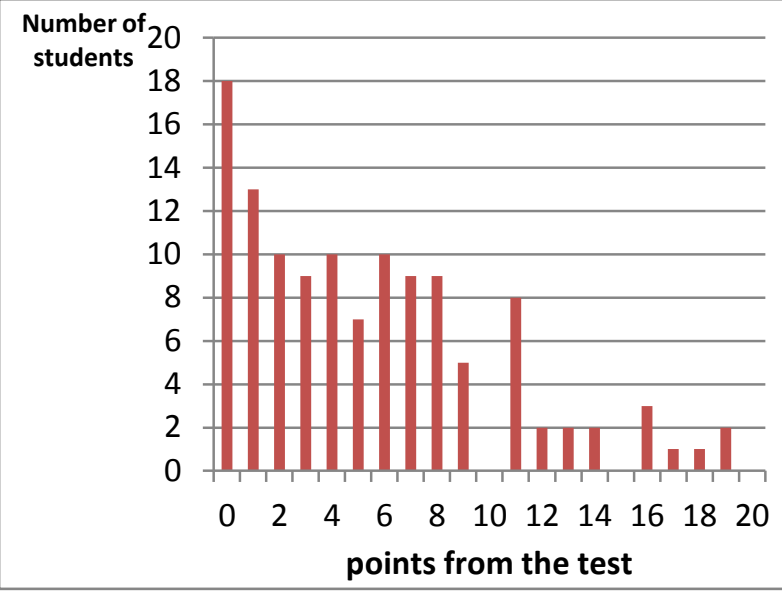

Table 4 shows the success depending on the date of the school-leaving exam. We can mention, although numbers of students are not too high, that students, who had passed the school-leaving exam this year, were not so successful as the "older" students.

Table 4. Test results.

\begin{tabular}{|c|c|c|c|}
\hline $\begin{array}{c}\text { the year of the } \\
\text { school-leaving } \\
\text { exam }\end{array}$ & $\begin{array}{c}\text { number of } \\
\text { all students }\end{array}$ & $\begin{array}{c}\text { number of } \\
\text { successful } \\
\text { students }\end{array}$ & $\begin{array}{c}\text { number of } \\
\text { students } \\
\text { from the } \\
\text { seminar }\end{array}$ \\
\hline 2017 & 117 & 16 & 0 \\
\hline 2016 & 29 & 5 & 21 \\
\hline other & 14 & 0 & 14 \\
\hline
\end{tabular}

Thus there were only 56 students who were able to continue this semester. If we compare numbers of successful students divided by the type of the secondary school, we obtain the following Table 5.

Table 5. Test results depending on the type of schools.

\begin{tabular}{|l|c|c|c|}
\hline type & $\begin{array}{c}\text { number of } \\
\text { all students }\end{array}$ & $\begin{array}{c}\text { number of } \\
\text { successful } \\
\text { students }\end{array}$ & $\begin{array}{c}\text { number of } \\
\text { students } \\
\text { from the } \\
\text { seminar }\end{array}$ \\
\hline school of economics & 56 & 17 & 8 \\
\hline hotel school & 74 & 0 & 24 \\
\hline technical school & 2 & 1 & 0 \\
\hline vocational school & 14 & 1 & 2 \\
\hline $\begin{array}{l}\text { comprehensive } \\
\text { school }\end{array}$ & 12 & 2 & 1 \\
\hline other & 2 & 0 & 0 \\
\hline
\end{tabular}

In Graph 3, you can see the percentage of the successful students depending on the type of schools.

Graph 3. The percentage of the successful students.

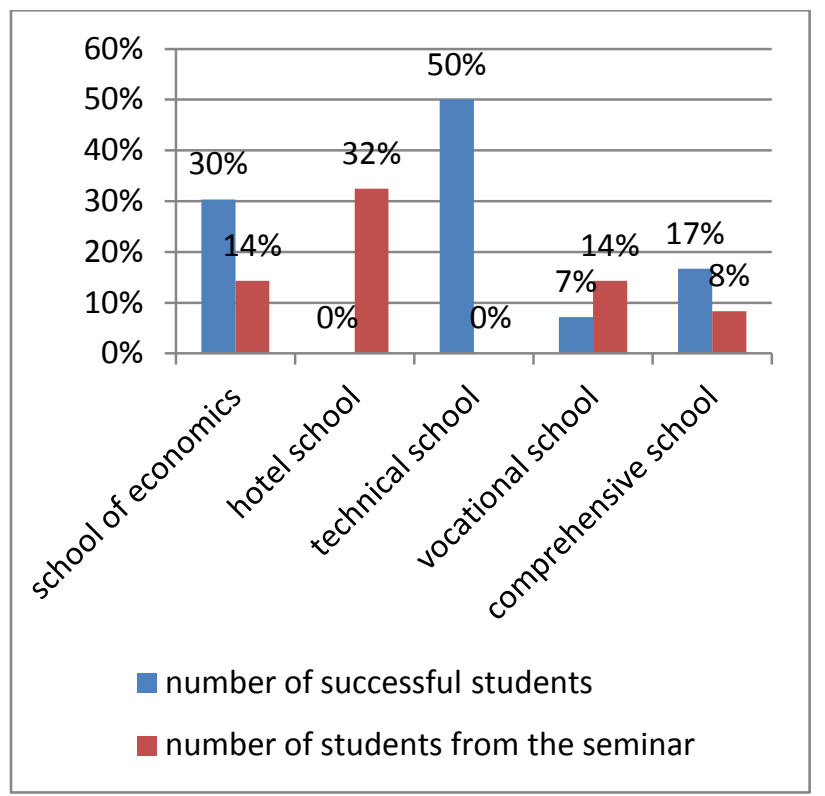

If we drop technical schools because of the low number of students, we can notice that schools of economics have the highest success rate. Despite the expectations students of the comprehensive schools have very low success rate. It is possible that these students have chosen VŠPJ as a replacement option, because they did not pass an entrance exam at university which they had wanted and they decided to stay at a school close to home instead. This is also the explanation why the programme of the study is not often close to the programme of their secondary school or to their abilities. As you can see from the Table 5, nobody from the students of hotel schools passed the test. We can attribute it to the fact that students from hotel schools have had less lessons of mathematics than students from other schools.

\section{Results of the second test}

Students who passed the first test then at the end of the semester had to write the second test. The test consisted from 6 exercises with theoretical questions as well. The students had to gain more than $50 \%$ of points to pass the test.

There were 29 successful students from the total number of 160 students and after the first test from the total number of 56 students. Thus, there was $18 \%$ success rate. The success in the second test does not depend so much on the case if the student attended the seminar before or not, as you can see in the Table 6 and Graph 4 and Graph 5.

Table 6. Type of schools

\begin{tabular}{|l|c|c|}
\hline & $\begin{array}{c}\text { number of all } \\
\text { students }\end{array}$ & $\begin{array}{c}\text { number of } \\
\text { successful } \\
\text { students }\end{array}$ \\
\hline $\begin{array}{l}\text { students who passed the } \\
\text { seminar }\end{array}$ & 35 & $19(54 \%)$ \\
\hline
\end{tabular}




\begin{tabular}{|l|l|l|} 
other & 21 & $10(48 \%)$ \\
\hline
\end{tabular}

Graph 4. The success of students who passed the seminar.

\section{Students who passed the seminar}

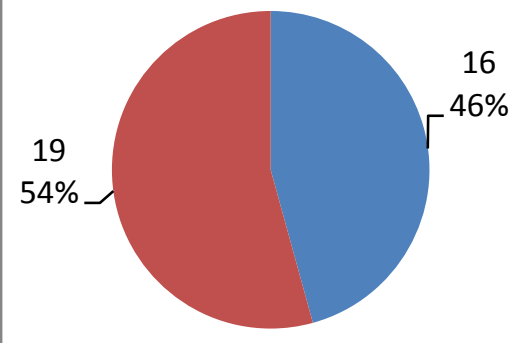

unsuccessful students

successful students

Graph 5. The success of students who did not pass the seminar.

\section{Students who did not pass the seminar}

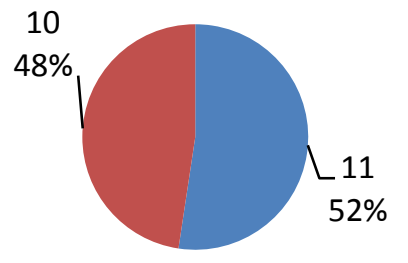

unsuccessful
students
successful
students

In the Table 7 you can see how the success depends on the type of secondary school. There are not any big differences.

Table 7. Test results depending on the type of schools.

\begin{tabular}{|l|c|c|c|}
\hline type & $\begin{array}{c}\text { number } \\
\text { of all } \\
\text { students }\end{array}$ & $\begin{array}{c}\text { number of } \\
\text { successful } \\
\text { students in } \\
\text { the first test } \\
\text { or seminar }\end{array}$ & $\begin{array}{c}\text { number of } \\
\text { successful } \\
\text { students in } \\
\text { the second } \\
\text { test }\end{array}$ \\
\hline school of economics & 56 & 25 & 13 \\
\hline hotel school & 74 & 24 & 12 \\
\hline technical school & 2 & 1 & 1 \\
\hline vocational school & 14 & 3 & 1 \\
\hline $\begin{array}{l}\text { comprehensive } \\
\text { school }\end{array}$ & 12 & 3 & 2 \\
\hline other & 2 & 0 & 0 \\
\hline
\end{tabular}

\section{Conclusion}

After analysis of the exams, it can be stated that the knowledge from topics of primary and secondary schools is only superficial, often poorly fixed. Many students have problems with simple algebraic expressions some of them cannot even use fractions, or powers and roots.
I have to point out that there were the students who had passed the school-leaving exam from mathematics this year, but they gained only one point from the maximum twenty in the first test. It is apparent that students study a topic for the "test time" and then they forget it immediately. This means that they do not understand a topic, and they have a tendency to mechanical learning of isolated facts and sample tasks. They reproduce some methods without understanding.

The aim of this article was to analyze the type of secondary school and success of students of the study programme "Travel and Tourism". I can determine that more successful in the first test were students from schools of economics. On the other hand the success in the second test of the students does not depend on the type of the secondary school. I have found that the knowledge of mathematics of our students is almost on the same level without differences between the secondary schools. It could be explain that our incoming students were not focused on the mathematics during their studies therefore they chose this study programme. Students often think that they will not need mathematics in "Travel and Tourism" or in their life anyway.

We can state that more successful are students who passed the seminar, see Table 6 . In addition, as you can see in Table 7, $50 \%$ of the students from the hotel schools (who had passed the seminar) passed the second test. Thus, I can conclude that the seminar was very helpful for these students.

There is always decrease of students after the first semester of their studies, but students who really want to finish their studies are motivated to do more, so we can see the growth of students who have registered into the Math seminar. I would like to consider this as a part of a long-term monitoring of students in this study programme and re-analyze unsuccessful students after they pass the course "Math seminar".

Another direction of the analysis is to identify parameters that have the greatest influence on the success of a student (for example use Pearson's Chisquare Test of independence) and use logistic regression model to build on the success of a student during the test.

\section{Acknowledgements}

This paper was processed with contribution of long term institutional support of research activities by Faculty of Informatics and Statistics, University of Economics, Prague.

\section{References}

1. Alnoor A.G., Yuanxiang G., Abudhuim F.S. Assessment Mathematics Teacher's Competencies., ERIC, 2007.

2. Boháč Z., Doležalová J., Kreml P. Selected aspects affecting study results in mathematics. In Proceedings of 14th Conference on Applied Mathematics, Bratislava, 2015. 
3. Boháč Z., Doležalová J., Kreml P Problémy studia v prvním ročníku VŠB - TU Ostrava. In Proceedings of 13th Conference on Applied Mathematics, Bratislava, 2014.

4. Crone T. M. What test scores can and cannot tell us about the quality of our schools, Business Review, 3, 2004.

5. Ellen P.W.A., Jansen \& Cor J.M. Suhre The effect of secondary school study skills preparation on first year university achievement, Educational Studies, 36:5, 2010.

6. Klůfa J. Entrance Exams - Analysis of Results in Mathematics, Winter global business conference and winter global education, teaching and learning conference. Tignes, 2018.

7. Klůfa J. Homogeneity of the Test Variants in Entrance Exams, 21st International Conference on Circuits, Systems, Communications and Computers, 2017.

8. Konečná P., Solárová M. Secondary school students'knowledge level in the field of application problems in mathemtics and chemistry. In Proceedings of 14th Conference on Applied Mathematics, Bratislava, 2015.

9. Kroupová M., Budíková M. Analysis of the failrates in a bachelor degree programme in mathematics and applied mathematics. In Proceedings of 14th Conference on Applied Mathematics, Bratislava, 2015.

10. Michaelowa $K$. The impact of primary and secondary education on higher education quality, Quality Assurance in Education, Vol. 15 Issue: 2, 2007.

11. Otavová, M., Sýkorová I. Analysis of differences in the scores of students from different faculties, In Proceedings of the 12th International Conference Efficiency and Responsibility in Education 2015 (ERiE). Prague: Czech University of Life Sciences Prague, 2015, s. 422--429. ISBN 978-80-213-2560-9.

12. Tanner, D.E. The competency test's impact on teachers' abilities, Urban Rev (1995) 27: 347. 